\title{
Ovularia pusilla, Hadrotrichum virescens, Deightoniella arundinacea and Discosia artocreas on grasses in Finland
}

\author{
Kaiho Mäkelä and Hilkka Koponen
}

University of Helsinki, Department of Plant Pathology, SF-00710 Helsinki 71, Finland

Present address: K. Mäkelä, Institute of Plant Pathology, Agricultural Research Centre, Box 18, SF-01301 Vantaa 30, Finland.

H. Koponen, Department of Botany, University of Helsinki, Unioninkatu 44, SF-00170 Helsinki 17, Finland.

\begin{abstract}
Material of this study consists of c. 4650 grass samples gathered on leys, field borders and forests throughout the country during 1966-1974. Collections of Department of Plant Pathology, and Botanical Museum, University of Helsinki, and Mr. Pentti Alanko's herbarium were also examined.

Ovularia pusilla (Ung.) Sacc. et D. Sacc. was found on 29 samples of 11 grass species: Agrostis borealis Hartm., A. tenuis Sibth., Calamagrostis canescens (Web.) Roth, C. epigeios (L.) Roth, C. purpurea Trin., Cinna latifolia (Trevir.) Griseb., Deschampsia caespitosa (L.) PB., D. flexuosa (L.) Trin., Festuca rubra L., Hierochloë odorata (L.) PB., and Poa annua L., throughout the country, being most common on $P$. annua.

Hadrotrichum virescens Sacc. et Roum. was found on nine specimens of four grass species: Agropyron repens (L.) PB., Agrostis stolonifera L., A. tenuis, and Poa Chaixii Vill. in some places as far as Lapland.

Deightoniella arundinacea (Sacc.) Hugh. was found on three specimens of three grass species: Calamagrostis purpurea, Molinia coerulea (L.) Moench, and Phragmites communis Trin. in the neighbourhood of Helsinki.

Discosia artocreas (Tode) Fr. was found on two specimens of two grass species: Lolium perenne L., and Melica nutans L. in Helsinki.

All these fungi were found to be accidental and infrequent, usually on wild grasses on field borders, and forests. All fungi are of negligible importance.
\end{abstract}

\section{Material and Methods}

This study is based on c. 4650 grass samples gathered throughout the country on leys, field borders, and forests. In Finland numerous wild grasses are common throughout the country (HULTÉN 1971). Besides several grass specimens were examined in collections of Department of Plant Pathology, HPP, Botanical Museum, University of Helsinki, H, and Mr. Pentti Alanko's herbarium.

Abbreviations of the Finnish biological provinces are in accordance with HEIKINHEI-
MO and RAATIK AINEN (1971).

Collectors were Pentti Alanko = P.A., Hilkka Koponen $=$ H.K., and Kaiho Mäkelä $=$ K.M.

Microscopic slides were prepared from all the samples bearing symptoms of the fungi. The slides were preserved in lactic-acid and lactophenol solution, where the fungi were also measured and photographed. The microphotographs were taken by Kaiho Mäkelä.

\section{Results and Discussion}

Ovularia pusilla (Ung.) Sacc. et D. Sacc. Syll. Fung. 18: 531, 1906, syn. Ramularia pusilla Ung. Exanth. Pfl. p. 169, 1833 (cf.
SACCARDO 1906: 531); $R$. pulchella Ces. Bot. Zeit. 11: 238, 1853; O. pulchella (Ces.) Sacc. Syll. Fung. 4: 145, 1886 (cf. LINDA U 


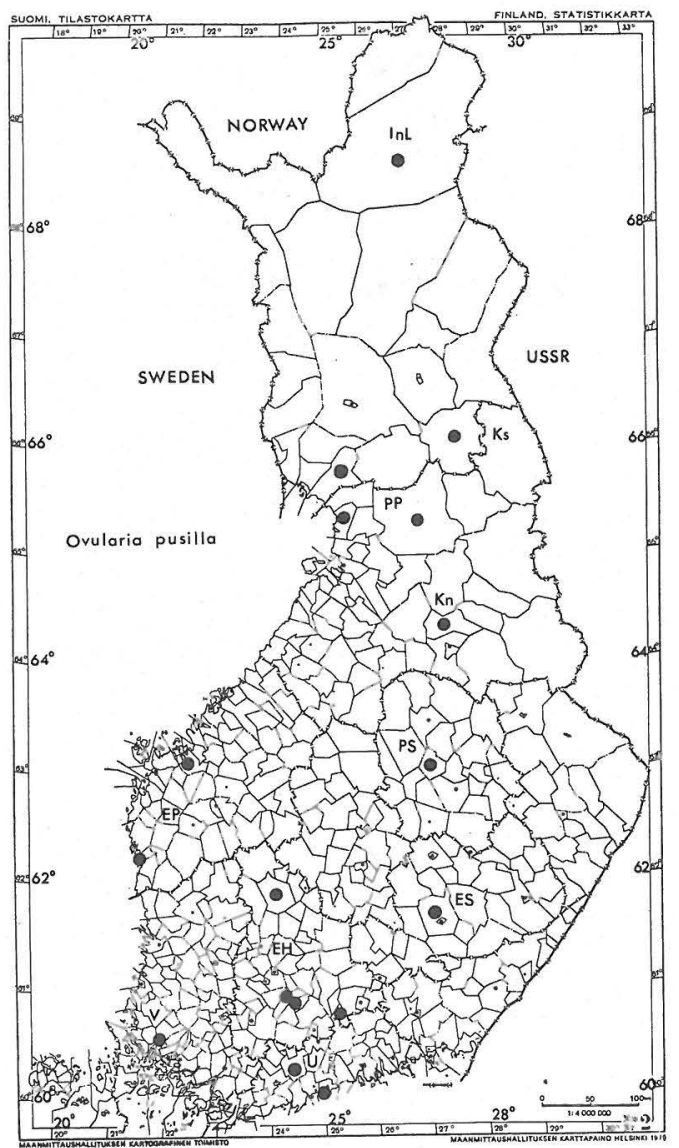

Fig. 1. The origin of Ovularia pusilla on grasses in Finland.

1907: 235, SPRAGUE 1950: 410).

Ovularia is a genus of Moniliales (AINSWORTH 1967). It causes leaf spot on various grasses in Europe, North America and New Zealand (LINDAU 1907, JりRSTAD 1945, SPRAGUE 1950, 1955, LATCH 1964).

In Finland (in H and HPP), the earliest specimens of $O$. pussilla has been found on Cinna latifolia (Trevir.) Griseb. in 1937 in PS: Maaninka, collected by Roivainen.

In the present study the fungus was found rare and infrequent throughout the country (Fig. 1), being most common on Poa annua L. (13 of 34 specimens studied). Besides the fungus was found accidentally in the following grasses: A. borealis Hartm. (one of 9 specimens studied), A. tenuis Sibth. (one of 363 specimens), Calamagrostis canescens (Web.) Roth (one of 41 specimens), C. epigeios (L.) Roth (one of 176 specimens), C. purpurea Trin. (one of 86 specimens), Deschampsia caespitosa
(L.) PB. (two of 158 specimens), D. flexuosa (L.) Trin. (one of 157 specimens), Festuca rubra L. (one of 269 specimens), and Hierocloë odorata (L.) PB. (one of 10 specimens studied). Most of the specimens of $O$. pusilla were collected in August (13. VII. - 2. XI.). According to the different authors the fungus has occurred on widely distributed grass species (cf. JøRSTAD 1945, SPRAGUE 1950, LATCH 1964).

O. pusilla causes leaf-spots, which vary according to the host. On Poa annua the centers of the spots are greyish orange - golden yellow - yellowish brown in colour. The margin is light yellow-reddish yellow in colour. The size of lesions is (0.5) 1.9 (7.0) $\mathrm{mm}$ long and (0.3) $1.0(2.5) \mathrm{mm}$ wide (Fig. 2).

The conidiophores are hyaline, simple or branched one-three septate (22) 52.5 (94) $\mu \mathrm{m}$ long, (1) 3.1 (5) $\mu \mathrm{m}$ wide. The conidia are few, hyaline, ellipsoidal to ovate, non-septate. At the point of attachment to the conidiophore there is a well-defined scar (Figs. 2 and 3 ). The size of conidia varies on different host: on Poa annua (8) 13.9 (21) $\mu \mathrm{m}$ long, (4) 7.4 (10) $\mu \mathrm{m}$ wide, Calamagrostis purpurea (9), 11.7 (14) $\mu \mathrm{m}$ long, (5) 6.5 (7) $\mu \mathrm{m}$ wide, Deschampsia caespitosa (10) 14.6 (18) $\mu \mathrm{m}$ long, (10) 10.7 (12) $\mu \mathrm{m}$ wide and Festuca rubra (8) 12.3 (16) $\mu \mathrm{m}$ long, (5) 7.6 (10) $\mu \mathrm{m}$ wide. In the present study the size of the fungus is rather similar than reported by SPRAGUE (1950) and LA TCH (1964).

\section{Examined material}

On Agrostis borealis:

InL: Inari 1. VIII. 1973 (H.K.).

On Agrostis tenuis:

Ks: Posio 8. VIII. 1973 (H.K.).

On Calamagrostis canescens:

EP: Vöyri 17. VIII. 1972 (H.K.).

On Calamagrostis epigeios:

PP: Ii 5. VIII. 1973 (H.K.).

On Calamagrostis purpurea:

EP. Vöyri 17. VIII. 1972 (H.K.).

\section{On Cinna latifolia:}

PS: Maaninka 31. VII. 1937 (H. Roivainen, H).

On Deschampsia caespitosa:

PP:Ii 26. VII. 1973 (H.K.), Pudasjärvi 8. VIII. 1973

(H.K.), Simo 5. VIII. 1973; InL: Inari 31. VII. 1973 (H.K.). 

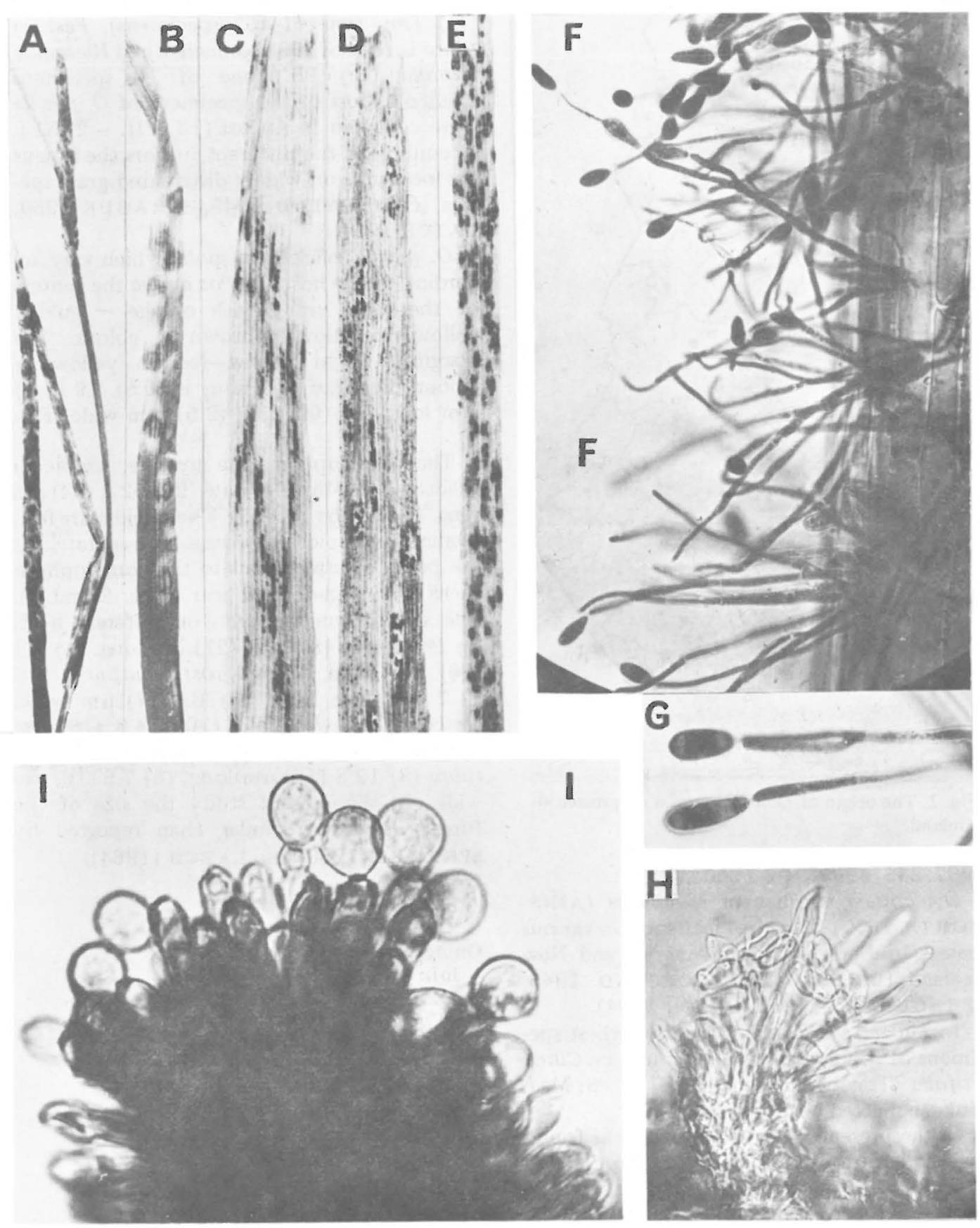

Fig. 2. Ovularia pusilla. A, B, F, G: on Poa annua, A, B: Mikkeli commune 28. VII. 1974, F. G: Hattula 13.VII. 1973; H: on Festuca rubra Ruovesi 23.VII. 1973. Hadrotrichum virescens.

C: on an unidentified grass Kuopio 1899, D: on Agropyron repens Ähtäri 25. IX. 1966, E: on Agrostis sp. Helsinki IX. 1913. A: x 1, B-E: x 2, F, H: x 500, G, I: x 1000. 

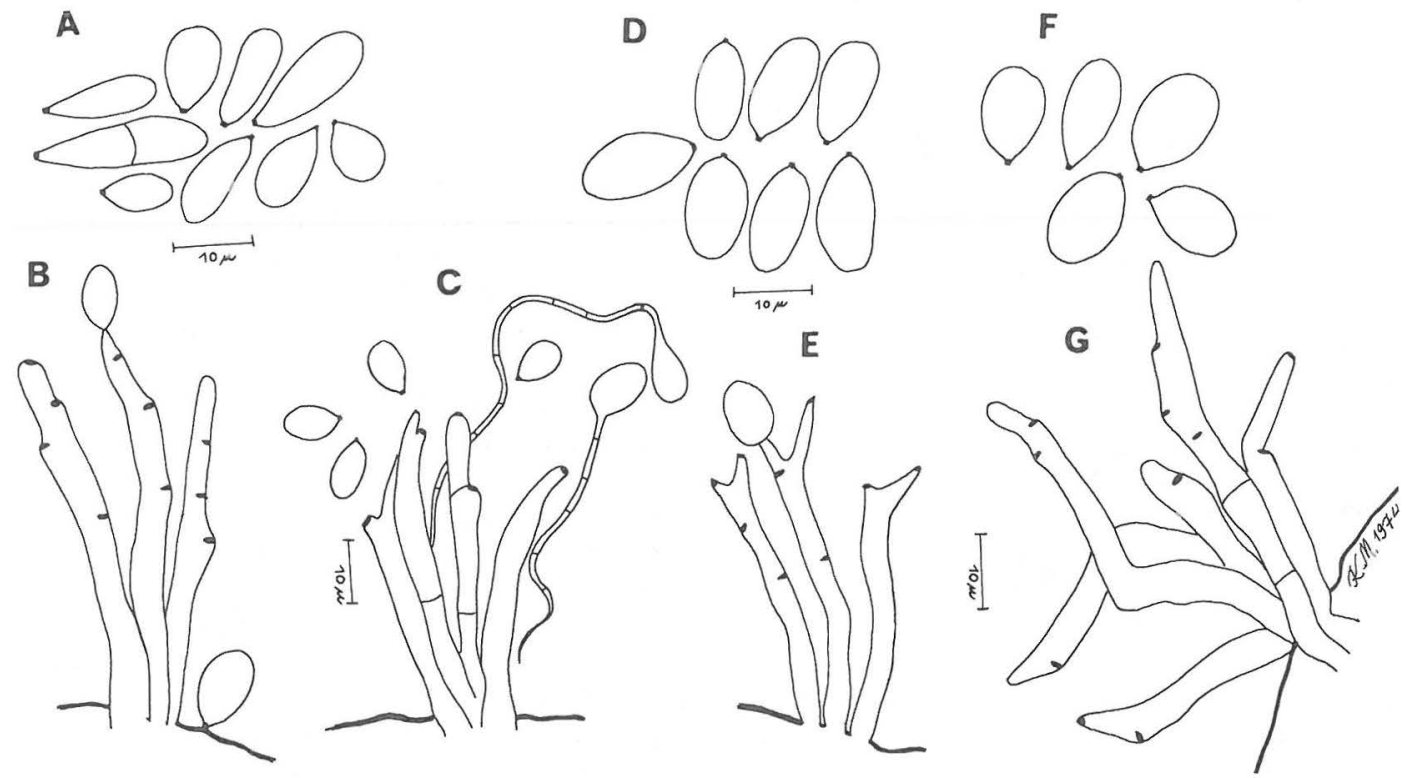

Fig. 3. Conidiophores and conidia of Ovularia pusilla. A, B: on Poa annua, A: Hattula 30. VIII. 1970, B: Paltamo 9. VIII. 1973, C: on Hierochloë odorata Mikkeli commune 29. VII. 1972, D. E: on Festuca rubra, D: Helsinki 2. VIII. 1972, E: Inari 31. VIII. 1973, F: on Calamagrostis canescens Vöyri 17. VIII. 1972, G: on C. epigeios Ii 5. VIII. 1973.

On Deschampsia flexuosa:

Ks: Posio 7. VIII. 1973 (H.K.).

On Festuca rubra:

V: Vihti 15. VIII. 1968 (K.M.); U: Helsinki 2. VIII. 1972 (H.K.); EH: Ruovesi 23. VII. 1973 (H.K.); Ks: Posio 7. VIII. 1973 (H.K.); InL: Inari 31. VII. 1973 (H.K.).

On Hierocloë odorata:

ES: Mikkeli commune 27. IX. 1972 (H.K.).

\section{On Poa annua:}

V: Mietoinen 30. VII. 1974 (H.K.); U: Helsinki 8. VIII. 1972 (H.K.); EH: Hattula 30. VIII. 1970 (K.M.), Hämeenlinna 17. VIII. 1970, 13. VII. 1973, 18. VIII 1974 (K.M.), Kärkölä 15. VIII. 1974 (H.K.), Ruovesi 23. VII. 1973 (H.K.); ES: Mikkeli commune 28. VII. 1974, 2. IX. 1974 (H.K.); EP: Björköby 2. XI. 1961 (H. Roivainen, H); Kristiinankaupunki 19.VIII 1972 (H.K.); Kn: Paltamo 9. VIII. 1973 (H.K.); Ks: Posio 7. VIII. 1973 (H.K.).

Hadrotrichum virescens Sacc. et Roum. Mich. II: 640 (SACCARDO 1886: 301, LINDAU 1907: 683). The perfect stage Scirrhia agrostidis (Fuck.) Winter 1887: 907.

Hadrotrichum is a genus of Moniliales (AINSWORTH 1967).

It causes leaf spot on grasses, particularly on Agrostis species in Europe and North America (LINDAU 1907, LIND 1913, PAPE 1928, GUY OT 1932, SIEMASZKO 1933, SAMPSON and WESTERN 1942, JøRSTAD 1945).

In Finland (in H and HPP), the earliest specimen of $H$. virescens has been found on $\mathrm{Ag}$ rostis stolonifera L. in 1899 in PS: Kuopio. H. microsporum Sacc. et Malbr. var. macrosporum Karsten (Acta Soc. Fauna et Flora Fenn. 27, $4: 11,1905)$ has been also found on $A$. stolonifera in the neighbourhood of Kuopio. According to GUYOT (1932), this species is only a pale-spored form of $H$. virescens. $H$. virescens has been also found on $A$. tenuis Sibth. in 1937, in Kainuu (LIR o 1953, Myc. Fenn. no. 844).

In the present study the fungus was found accidentally here and there in Finland (Fig. 4). It was found on Agrostis tenuis (two of 363 specimens studied), and Agropyron repens (one of 230 specimens). The specimens were collected between April 2 and September 27.

The fungus causes dark, olive green - dark brown spots on leaves of grasses, resembling often telia of Puccinia coronata (cf. JøR ST AD 1930).

Conidiophores are closely packed together, unbranched, cylindrical structures, septate, (20) 29.0 (40) $\mu \mathrm{m}$ long, (4) 6.1 (8) $\mu \mathrm{m}$ wide. Conidia were terminating in single, spherial, echinulate, dark oliver green (8) 12.3 (16) $\mu \mathrm{m}$ 


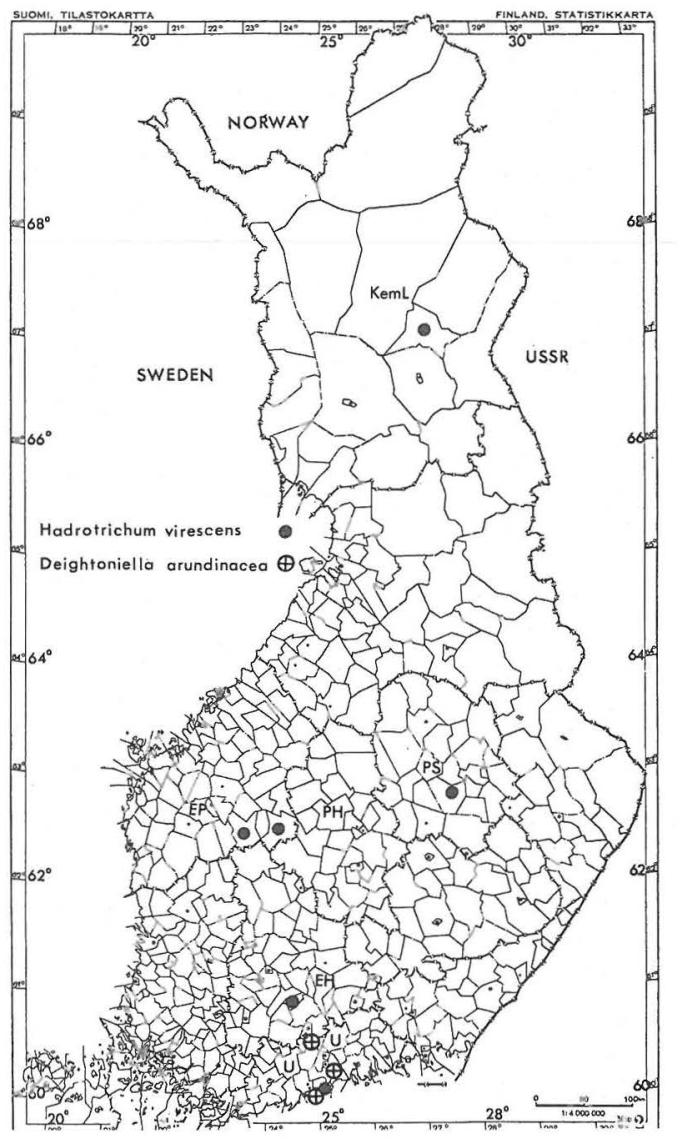

Fig. 4. The origin of Hadrotrichum virescens and Deightoniella arundinacea on grasses in Finland.

in diam. (Fig. 2). In the present study the size of the fungus is rather similar than reported by LINDAU (1907), GUYOT (1932) and SAMPSON and WESTERN (1942).

Examined material

On Agropyron repens:

EH: Hämeenlinna 30. VII. 1937 (Liro \& Roivainen, H); PH: Ähtäri 25. IX. 1966 (P.A., H).

On Agrostis stolonifera:

PS: Kuopio 30. VIII. 1899 (O. Lönnbohm, H); PK: Kitee VIII. 1904 (O. Lönnbohm, H).

On A. tenuis:

EP: Alavus 27. IX. 1966 (P.A.); Kn. Kiehimä 6. VIII. 1937 (H. Roivainen, H); KemL: Pelkosenniemi 7. VIII. 1973 (H.K., HPP); EnL: Vähäniva 11. VII. 1936 (T. Putkonen, H).

On Agrostis sp.:

U. Helsinki IX. 1913 (T. Putkonen, HPP), 2. IV.
1930 (Liro \& Heikinheimo, H).

On Poa Chaixii Vill.:

St: Pirkkola 30. VI. 1908 (O. Collin \& O. Saarlund, HPP).

Deightoniella arundinacea (Corda) Hughes, Canad. J. Bot. 31: 574, 1953, syn. Helminthosporium arundinaceum Corda. Icon. Fung. III: 10, 1839, Napicladium arundinaceum (Corda) Saccardo. Syll. Fung. IV: 482, 1886 (cf. LINDAU 1910: 73).

Deightoniella is a genus of Moniliales (AINSWORTH 1967).

$D$. arundinacea occurs on living or dead leaves of grasses, particularly on Phragmites communis Trin. It is wide-spread in Europe and North America (SACCARDO 1886, LINDAU 1910, LIND 1913, HUGHES 1953).

In Finland the fungus has been known since 1884 on Phragmites communis in $\mathrm{EH}$ : Mustiala (KARSTEN 1884a: 26).

In this study the fungus was found accidentally on four specimens of three grass species in the neighbourhood of Helsinki (Fig. 4). The fungus was found on Molinia coerulea (L.) Moench (two of 16 specimens studied), Calamagrostis purpurea Trin. (one of 86 specimens) and Phragmites communis (one of 34 specimens). The specimens were collected between July 7 and August 6 .

$D$. arundinacea causes on living leaves, large irregular necrotic streaks and necrotic areas which may extend the length of the blade, olive grey - brownish grey in colour (Fig. 3). The conidiophores grow dense and arise from intraepidermal cells (Fig. 5). They are rather short, (20) 38 (44) $\mu \mathrm{m}$ long and 4-6 (9) $\mu \mathrm{m}$ wide, 1-3-septate. Successive conidia develop on successive proliferations through previous conidial scars, olive grey in colour (Fig. 3). The size of conidia is similar on different hosts, (21) 34.8 (42) $\mu \mathrm{m}$ long, (11) 14.0 (17) $\mu \mathrm{m}$ wide, (2) 3 (4)-septate. In the present study the length of conidiophores is shorter but that of conidia is rather similar than reported by SACCARDO (1886) and LINDAU (1910).

\section{Examined material}

On Calamagrostis purpurea:

U: Hyvinkää 6. VIII. 1972 (H.K., HPP).

On Molinia coerulea:

U: Helsinki 7. VII. 1970 (P. Ilonoja, HPP), Hyvinkää 6. VIII. 1972 (H.K., HPP).

On Phragmites communis:

U: Sipoo 11. VII. 1970 (P.A.). 

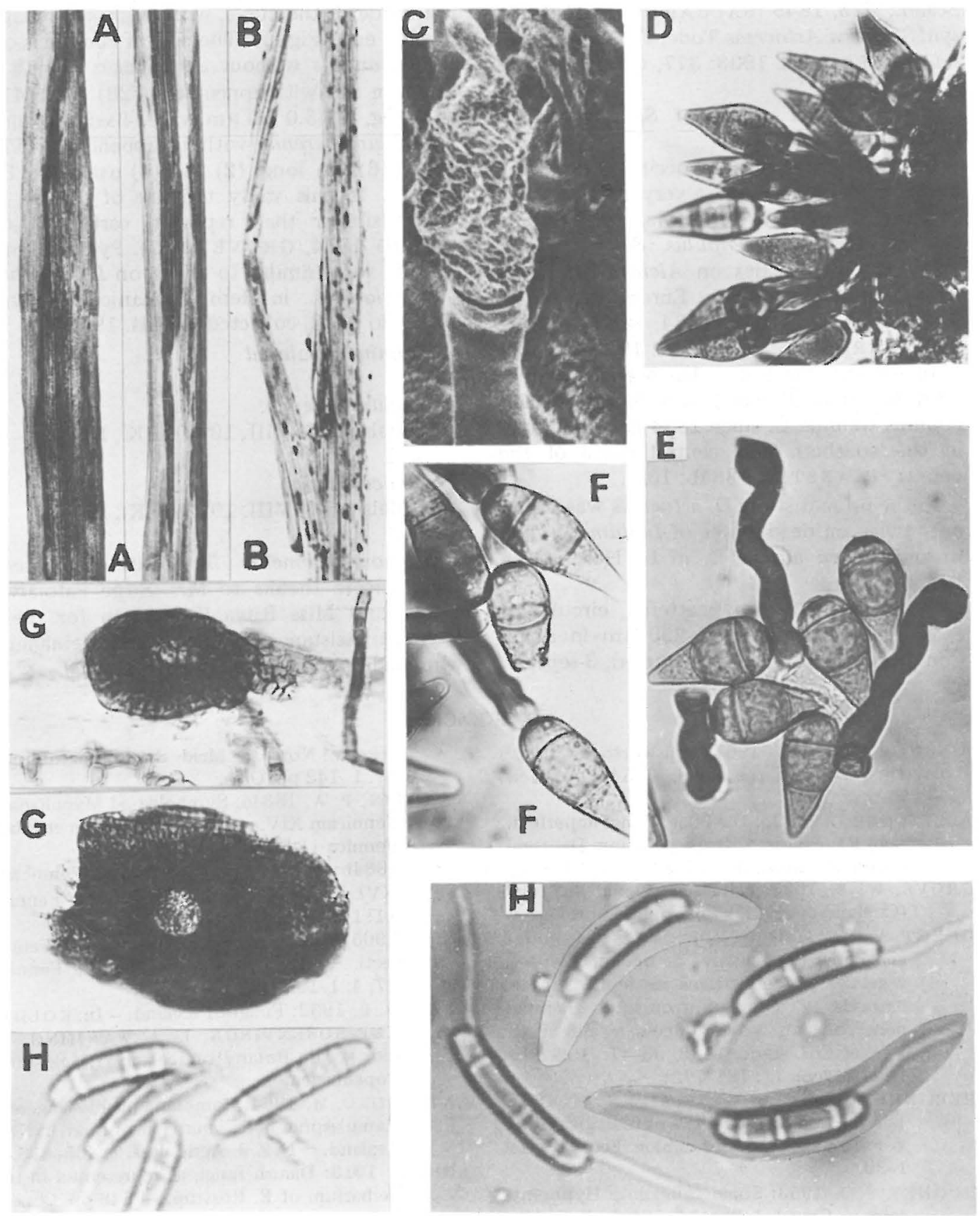

Fig. 5. Deightoniella arundinacea. A, C, D, F: on Molinia coerulea, E: on Calamagrostis purpurea, A, C, D: Helsinki 7. VII. 1970, E, F: Hyvinkää 6. VIII. 1972. Discosia artocreas. B, H: on Melica nutans, Helsinki 8. VIII. 1972, G: on Lolium perenne, Helsinki 2. VIII. 1972. A, B: x 2, C: x 2500, SEM, Viikki, D: x 800, F, E: x 1000, G: x 250, H: x 2000. 
Discosia artocreas (Tode) Fr. Summa veg. Scand., 423, 1849 (SACCARDO 1884: 653), syn. Sphaeria Artocreas Tode, F. Meckl. II: 77 (cf. ALLESCHER 1903: 377, GROVE 1937, II: 189).

Discosia is a genus of Sphaeropsidales (AINSWORTH 1967).

It has been known to occur common on living or dead leaves on a very great number of trees, shrubs, and herbs, viz. Acer, Betula, Corylus, Crataegus, Populus, Salix, Sorbus, Tilia etc. and besides on Alchemilla, Epilobium, Ranunculus etc. in Europe and North America (SACCARDO 1884, ALLESCHER 1903, LARSEN 1932, GROVE 1937).

In Finland the fungus has been known on dead leaves of Betula pubescens Ehrh. and Populus tremula L. since 1884 here and there in the southern and central parts of the country (KARSTEN 1884b: 158).

In the present study $D$. artocreas was found only twice on dead leaves of Lolium perenne L. and Melica nutans L. in U: Helsinki, in 1972.

Pycnidia are brown, scattered, circular or oval, flattened, about $90-250 \mu \mathrm{m}$ in diam. Conidia are hyaline, slightly curved, 3-septate, furnished on one side of the rounded apex, on the inside of the curve, with single appendage at each end (Fig. 5). The size of conidia is on Melica nutans without appendages (9) 15.3 (19) $\mu \mathrm{m}$ and with appendages (20) 36.3 (41) $\mu \mathrm{m}$ long, (2) 3.0 (4) $\mu \mathrm{m}$ wide, 4-septate, and on Lolium perenne without appendages (11) 12.9 (16) $\mu \mathrm{m}$ long, (2) 2.6 (3) $\mu \mathrm{m}$ wide, 3septate. In this study the size of conidia is rather similar than reported earlier (SACCARDO 1884, GROVE 1937). Pycnidia and conidia were similar to those on Lysimachia nummularia L. in Herb. Ramanicum (Săvulescu) no 1382, collected 3. VIII. 1942.

\section{Examined material}

\section{On Lolium perenne:}

U: Helsinki 2. VIII. 1972 (H.K., HPP).

\section{On Melica nutans:}

U: Helsinki 8. VIII. 1972 (H.K., HPP).

Acknowledgements. The authors express their sincere thanks to Mrs. Sirpa Palojärvi, M.Sc., and Miss Ritva Kauppinen for their technical assistance, and Mr. Pentti Heinänen, who made photographs.

\section{REFERENCES}

AINSWORTH, G. C. 1967: Ainsworth \& Bisby's Dictionary of the fungi. - $547 \mathrm{pp}$. Kew, Surrey.

ALlescher, A. 1903: Die Pilze. Fungi imperfecti. - In Rabenhorst's Kryptog. -Flora Deutschl. Ósterr. Schweiz, 2nd ed., I(VII): 1-1072.

GROVE, W: B. 1937: British stem- and leaf-fungi (Coelomycetes) II. -406 pp. Cambridge.

GUYOT, A. L. 1932: Observations sur la distribution géographique comparée de quelques espèces végétales et de certains de leurs parasites naturels. ( $2^{\mathrm{e}}$ Note). Sur quelques champignons parasites des Graminées. - Rev. Path. Vég. et Ent. Agric. 19, 2: 36-47. (Ref. Rev. Appl. Mycol. 11:721-722).

HEIKINHEIMO, O. \& RAATIKAINEN, M. 1971: The recording of localities of biological finds in Finland. - Ann. Entomolog. Fenn. 37, 1a: $1-30$.

HUGHES, S. J. 1953: Some foliicolous Hyphomycetes. - Canad. J. Bot. 31: 560-576.

HULTEN, E. 1971: Atlas of the distribution of vascular plants in northwestern Europe. 531 pp. Stockholm.

JøRSTAD, I. 1930: Beretning om plantesykdommer i land- og hagebruket VI. Sykdommer på korn- og engvekster. -84 pp. Oslo.

- 1945: Parasittsoppene på kultur- og nytte- vekster i Norge. - Meld. Stat. Pl. patol. Inst. Nr. 1.142 pp. Oslo.

KARSTEN, P. A. 1884a: Symbolae ad Mycologiam Fennicam XIV. - Medd. Soc. Fauna et Flora Fennica 11:21-27.

- 1884b: Symbolae ad Mycolagiam Fennicam XVI. - Medd. Soc. Fauna et Flora Fennica 11: 148-161.

- 1905: Fungi novi nonnullis exceptis in Fennia lecti. - Acta Soc. Fauna et Flora Fennica 27, 4: 1-16.

LARSEN, P. 1932: Fungi of Iceland. - In: KOLDERUP-ROSENVINGE, L. \& WARMING, E. (eds.). The Botany of Iceland II: 449-607. Copenhagen.

LA TCH, G. C. M. 1964: Ramularia pusilla Ung. and Ramulaspora holci-lanati (Cav.) Lind. in New Zealand. - N. Z. J. Agric. Res. 7: 405-416.

LIND, J, 1913: Danish fungi, as represented in the herbarium of E. Rostrup. - 648 pp. Copenhagen.

LIN DA U, G. 1907: Die Pilze. Fungi imperfecti. In: Rabenhorst's Kryptog.-Flora Deutschl. Österr. Schweiz, 2nd ed., I(VIII): 1-852.

- 1910: Die Pilze. Fungi imperfecti. - In: Rabenhorst's Kyrptog.-Flora Deutschl. Österr. Schweiz, 2nd ed., I(IX): 1-983.

LIR O, J. I. 1953: Mycotheca Fennica. Die Etiketten 
N:o 601-900. ed. H. Roivainen. - 102 pp. Helsinki.

PAPE, H. 1928: Krankheiten und Schädlinge der Futter- und Wiesenpflanzen und ihre Bekämpfung. - Deutsche Landw. Presse 6: 83; 18: 270; 25: 378; 28: 418. (Ref. Rev. Appl. Mycol. 7: 641-642).

SACCARDO, P. A. 1884: Sylloge Fungorum III 860 pp. Patavii.

- 1886: Sylloge Fungorum IV - 807 pp. Patavii.

- 1906: Sylloge Fungorum VIII - 838 pp. Patavii.

SAMPSON, K. \& WESTERN, J. H. 1942: Diseases of British grasses and herbage legumes. 85 pp. Cambridge.

SIEM ASZK O, w. 1933: Quelques observations sur les maladies des plantes en Pologne. - Rev. Path. Vég. et Ent. Agric. 20: 139-147. (Ref. Rev. Appl. Mycol. 12:550).

SPRAGUE, R. 1950: Diseases of cereals and grasses in North America. - 538 pp. New York.

- 1955: Some leafspot fungi, on western Gramineae. IX. - Mycologia 47: 835-845.

WiNTeR, G. 1887: Die Pilze. Ascomyceten: Gymnoasceen und Pyrenomyceten. - In: Rabenhorst's Kryptog.-Flora Deutschl. Österr. Schweiz, 2nd ed., I(II): 1-928.

Received 21. 11. 1974. 